\title{
Defending poetry, or, is there an early modern aesthetic?
}

\author{
Is there an early modern aesthetic? \\ Or, better:
}

What does one call the space currently occupied by aesthetics before aesthetics emerges?

This question appears within the space occupied by what has become known in certain literary-critical circles as the early modern period, broadly defined as $1500-1700 .^{1}$ Formulation of the idea of the early modern can be taken as an exemplary moment in the permeation of a 'new' historicism through literary studies since the early 1980s, most obviously through the twin historicisms of cultural materialism and cultural poetics (or 'new historicism'). ${ }^{2}$ The periodising title early modern is part of a movement away from notions such as 'the English Renaissance' or from 'the Tudor period', although such names are retained by some of historicism's adherents. ${ }^{3}$ That the emergence of the phrase 'early modern' seems to mark a strategic attempt to delineate what otherwise appears to be a depressingly familiar ramification of what I suppose we must now term 'old' historicism doesn't diminish its institutional effectivity. ${ }^{4}$

One area that has created concerns about the new historicist project is its treatment of aesthetics. 'Cultural poetics', previously Stephen Greenblatt's preferred term for his form of criticism, makes clear the expansion of 'poetics' into a domain that is no longer strictly associated with 'poetry' (widely conceived). 5 Aesthetics has been expanded as a term within new historicist discourse to encompass any form of symbolic interaction that is susceptible to (literary-) critical analysis. As Catherine Gallagher and Greenblatt have argued:

In the analysis of the larger cultural field, canonical works of art are brought into relation not only with works judged as minor, but also with texts that are not by anyone's standard literary. The conjunction can produce almost surrealist wonder at the revelation of an unanticipated aesthetic dimension in objects without pretensions to the aesthetic. ${ }^{6}$

This sense of wonder is crucial to Greenblatt's (and Gallagher's) project. ${ }^{7}$ Eschewing theoretical formulations, new historicism favours an attention to 'particularity' over what is considered to be the universalising impulse of more rigorously delineated 
critical projects. ${ }^{8}$ Thus the readings of 'social energies' produced, encompassing objects and practices that are not bounded by an aesthetics that takes art as its focus, deliberately offer no systematic place for the aesthetic. ${ }^{9}$ Part of the reasoning behind this is a desire to avoid falling back into a conservative notion of the 'special' quality of art in which, as Gallagher and Greenblatt put it, 'The rest of human life can only gaze longingly at the condition of the art object, which is the manifestation of unalienated labour, the perfect articulation and realization of human energy'. ${ }^{10}$ Certainly such an aesthetic idealism does not seem to offer a fruitful avenue for enquiry. But does a more narrow conception of the aesthetic than that offered by new historicism necessarily entail such a vision of unity, lack of alienation and perfection? Part of the purpose of this essay is to suggest that this form of idealism was always an illusion, but that this does not mean that it can so easily be dismissed.

Tellingly, in the narrative given in Practicing New Historicism, one of the main impulses behind the authors' approach comes not from within early modern culture, but instead from Herder. ${ }^{11}$ Thus new historicism locates itself within the ambit of German Romanticism/Idealism and its inheritances, seeking to read the early modern in terms of an aesthetic that is post-Kantian (although not Kantian) rather than being itself early modern. This should not be surprising. Indeed, new historicist discourse frequently foregrounds its imbrication with present concerns, but tends to be selective about what those concerns are. ${ }^{12}$ So while it would not be possible simply to avoid the impact of a modern notion of aesthetics on contemporary critical practices, it is worth giving further consideration both to the relationship between modernity and early modernity, and to the role of the aesthetic within modernity itself. It will then be possible to look to an early modern text on the role and functions of art, Sidney's A Defence of Poetry, in order to begin to address more fully my opening question.

Hugh Grady has been one of the most consistently interested critics of recent years in the modernity of the early modern, and in a series of books he has focused his work on Shakespeare. ${ }^{13}$ As Grady has pointed out, however, the term early modern has itself been employed with a certain degree of ambivalence:

Widespread use of the term early modern expresses much of the ambiguity [around the question of Shakespeare's modernity] by positing both continuity and difference: the era is part of modernity but it's 'early' modernity. While Stephen Greenblatt has called for something like a revival of Burckhardt's idea of Renaissance modernity, critics such as Catherine Belsey and Jonathan Dollimore have followed T. S. Eliot, making of the Renaissance a premodern transitional age in which discourses from an earlier medieval mentality overlap newer ones from the Age of Absolutism and an embryonic modernity. ${ }^{14}$

Leaning more towards what he identifies as Greenblatt's view, Grady suggests that rather than seeing Shakespeare (who here almost seems to stand in for the early modern tout court) as caught between a residual medieval position and a modern humanistic one (a view which he sees particularly in Belsey's work), it is possible 'that Shakespeare was working from a mentality that was specific to his own phase of early modernity'. ${ }^{15}$ One aspect of the problem is that the term early modern is a slippery and ill-defined one for the most part, especially in its relation to the modern, and consequently in 
different contexts ' modern and early modern overlap and compete with each other'. ${ }^{16}$ When Grady comes to discuss his sense of Shakespeare's modernity in this essay, he provides a familiar set of characteristics which he wishes to call modern: instrumental reason, power and autonomous subjectivity. Any philosophical notion of aesthetics becomes submerged in talk of the effects of a 'postmodern' aesthetic of discontinuity, and Shakespeare emerges as 'distant enough from modernity to be its critic, implicated in its logic and dynamics enough to speak to us of its unfulfilled possibilities' ${ }^{17}$ The aesthetic here, then, is almost entirely negative. It is seen to be part of a modernity that it is not significant in shaping in conceptual terms, and its role for Grady is as a marker of critical distance and a reminder of unfulfilled possibilities. What of the possibilities that were fulfilled? They are seemingly not Grady's concern. For Grady, then, the early modern (as Shakespeare) is not modern, but it remains modern enough to be recognisable in its differences from modernity. This is plausible enough, since anything that was absolutely different would be unrecognisable. It seems clear, though, that Grady's ambivalence to the term early modern hinges on a concept of the early modern that is itself ambivalent. Further, what lies behind this is a more deep-seated ambivalence towards modernity itself. Grady's attempt to find a 'mentality' specific to the early modern period, rather than one defined as between the modern and the medieval, should suggest that we look more closely at what lies within both modern and early modern aesthetic discourses.

\section{Aesthetics and modernity}

To repeat: What does one call the space currently occupied by aesthetics before aesthetics emerges? Let me recall what prompted me to consider such a question in the first place. In part, I was motivated by a series of concerns about definitions of modernity that necessarily impact upon the emergence of the idea of the early modern. Reading The Fate of Art, Jay Bernstein offered what seemed in many respects to be a compelling delineation of modernity, which Bernstein sees as beginning with the Kantian critical project, remarking that 'it is Kant's third Critique that attempts to generate, to carve out and constitute, the domain of the aesthetic in its wholly modern signification' ${ }^{18}$ We have to begin with this wholly modern signification. Outlining Kant's attempt to separate the categories in the process of delimiting pure and practical reason, and thus to establish a division of art from truth and goodness that persists in the notion of autonomous art, Bernstein notes the crucial role that aesthetics plays in the articulation of Kant's critical philosophy as a whole. Indeed, the question of philosophical aesthetics is the question of philosophy as system. For Kant, as for Hegel, the role of the aesthetic is crucial to the elaboration of a systematic critical project, that is, for the possibility of the closure of this thought as system. The aesthetic, then, is not something to be added to philosophy, nor is it simply one branch of philosophy among others. It is, rather, that which allows for a crucial step in philosophy's project of completing itself. We might say that a philosophy without aesthetics is not a philosophy, and certainly not a critical philosophy. Equally, we must not think of aesthetics in terms of a category that is separated or separable from this philosophical context, from 
a context which always conceptualises the aesthetic in relation to (in Kantian terms) theoretical and practical reason. ${ }^{19}$

Reason, then, always provides the framework for the discussion of aesthetics. The context for this post-Romantic 'story' of aesthetics is usefully reconstructed by Andrew Bowie, following Gadamer. In a trajectory which stretches from Kant and Baumgarten through German Idealism to Nietzsche and Schopenhauer, Bowie suggests that the crucial aspect of the story of aesthetics is 'the relationship between competing claims to truth' but that, as Gadamer indicates, 'one cannot presuppose that the nature of the division between philosophy and art can be truly defined by philosophy'. ${ }^{20}$ In freeing art from instrumental social functions, German Idealism stresses the role of the imagination in going beyond particular rules of and for art: 'Instead of being conceived of principally in terms of mimesis, representation, or entertainment, art begins to be conceived of in terms of its ability to reveal the world in ways that may not be possible without art. ${ }^{21}$ This is a shift, then, not just in how art is conceived as an object, but also in terms of its functions. The terms which are here being abandoned, such as mimesis and representation, are central to early modern debates about art, and to the classical tradition from which these debates are derived, and I will return to these ideas later. The central thing to note at this point is the connection between art and truth.

The truth offered or revealed by art is the point from which Bernstein begins. The categorial separation of domains in Kant's critical philosophy does not in itself, suggests Bernstein, offer any real problems to those who believe in a notion of enlightened modernity, but it must be related to the parallel move to use aesthetic judgement to prove the underlying unity of reason. This far less successful Kantian move, argues Bernstein, opens the space in which it is possible to read the emergence of the critique of enlightened modernity, since the fragmentation of reason that the categorial separation reveals may be seen to mirror the fragmentation of modernity itself. This establishes a line of critical thought that we might for convenience's sake call Hegelian. From this recognition of the failure of Kant's move in the Critique of Judgement, and its consequences for the idea of the autonomous artwork in modernity, Bernstein puts forward his notion of 'aesthetic alienation'. ${ }^{22}$ In this alienated form, aesthetics suffers mourning for its separation from reason and morality, and the 'fate' of art of Bernstein's title refers to this alienation from truth. Having stressed the importance of a sense of mourning to modernity, Bernstein reads in the third critique what he calls a 'memorial aesthetics', in which pain is brought together with the experience or production of pleasure. Bernstein cites Kant's own example in the third critique of the possibility of feeling some pleasure in a painful experience, which is that of the mourning widow who simultaneously remembers both her loss and the worth of her dead husband. It is tempting to read the widow as an allegorical figure for the position of the philosopher who wishes to preserve both the critical and systemic ambitions of the critical philosophy.

For Bernstein, the loss of the systematic unity of Kant's critical project is not to be read as a purely negative fall from a rational grace, since the critical element of the project need not be abandoned. To those who would wish to save Kant from his trou- 
blingly aporetic reading of the third critique, Bernstein proposes that 'Resistance to the memorialization of aesthetics on the grounds that it destroys the universality of Kant's critical system through the introduction of an essentially aporetic moment, a non-recuperable indeterminacy at the core of determinate reason, is nonetheless misplaced since it ignores the fact that his metaphysics was aporetic from the beginning', adding that 'to ignore the moments of limit and opacity in the critical system is to render it uncritical'. ${ }^{23}$ Resistance is, then, misplaced if it is motivated by a desire to preserve an illusory integrity, since the unity for which it offers to stand guard can only be sustained by ignoring the critical integrity of the critical system. In other words, to be critical is more important, ultimately, than to be systematic, and clearly any system could only be produced through and as a result of the critical integrity of any rational approach. One way to think through this might be to say that the critical aspect of Kant's project is doubled or enfolded, in that it acts as a form of resistance to its systemic ambitions. It remains necessary to be systematically critical, even if that critical element disrupts the system that it is supposed to guarantee.

It seems pertinent to consider further what relationship Grady's ambivalent periodisation bears to Bernstein's Habermasian characterisation of modernity, and thus to turn again to the question embedded in my title: is there an early modern 'aesthetic'? One of the problems for a historicist attempt to answer this question is that the spectre of anachronism is involved here, not least because it is well accepted that the term 'aesthetics' itself is first used by Baumgarten in 1735, and that the system of the arts to which it refers emerges in the eighteenth century. ${ }^{24}$ The emergence of aesthetics in this period marks an attempt to make a decisive shift away from discourses of art that focus upon rules and prescriptions; in other words, aesthetics emerges as that which is not poetics or rhetoric. As Cynthia Chase has argued: 'The rise of aesthetics happens concurrently with the fall of rhetoric: it is the institutionalised discipline of "Rhetoric" that is displaced by aesthetics, and it is the power of "rhetoric" that is castigated in the literature and the politics which in this respect it may be right to call "romantic". ${ }^{25}$ Rhetoric is not then just replaced; it is explicitly abjected in romanticism. It is this negative valuation of rhetoric within the post-romantic tradition that we must think beyond if we are to encounter that which occupies the space of aesthetics in the pre-romantic period, and yet it must not simply be assumed that this is possible. In part this is because any notion of a sudden division of pre- and post-romantic thought is dubious as well as hard to define, but it is also because any rational enquiry must proceed according to categories, concepts and procedures fully imbricated with this romantic inheritance.

\section{From cultural poetics to poetics}

Certainly, 'aesthetics' in the post-Kantian terms with which we are familiar did not exist in the sixteenth and seventeenth centuries in England, and the matter of aesthetics must be traced in a submerged form in discussions of poetics and rhetorics in this period, as well as reconstituted from what is frequently a very self-reflexive literary culture. ${ }^{26}$ The treatment of rhetoric identified by Chase inevitably raises the question of what precisely is being abjected. Alongside reading the often prescriptive 'how to' 
manuals of poetics and rhetoric, it is important in attempting to assess early modern discourses on art to look to the various prefaces, epistles, dedications and other paratexts that frame both literary and non-literary texts, as well as to read those moments in the texts themselves in which their own textuality becomes an explicit matter of concern. ${ }^{27}$ Metatheatricality has long been a topic of critical interest in the study of Renaissance drama, and there are similarly metapoetic and metarhetorical elements to be found in verse and prose. ${ }^{28}$

Of course, in constituting this reflexivity, much of this material reflects a classical inheritance, which often follows and disrupts the 'Aristotelian' division between poetics and rhetoric. The question of poetics is opened up in Aristotle's work through an emphasis on mimesis, and all of the poetic forms that he discusses are treated as 'modes of imitation', including not just poetry (in the linguistic sense) but also music (flute-playing and lyre-playing). ${ }^{29}$ In this, Aristotle is picking up on the discussion in Book X of Plato's Republic, in which the poet also appears as an imitator. ${ }^{30}$ Here it is part of an argument about the relationship between appearance, reality and truth, and art is thought of in terms of other forms of making (that is, as poiesis). Again, it is the relationship of art to truth that is central to the debate. The notably negative conception of poetry in this section of the Republic condemns poets, like all imitators, to a position at 'the third remove from truth', arguing that 'the imitator knows nothing worth mentioning of the things he imitates, but that imitation is a form of play, not to be taken seriously, and that those who attempt tragic poetry, whether in iambics or heroic verse, are all altogether imitators' ${ }^{31}$ Such a view of art as fundamentally nonserious and parasitic upon reality continues even into the work of modern ('analytic') philosophers such as J. L. Austin. ${ }^{32}$

Poetry in this Platonic and/or Aristotelian sense includes everything that we have come to call literature. Against this emphasis on mimesis in the definition of poetics, in rhetoric, for Aristotle, 'The modes of persuasion are the only true constituents of the art: everything else is mere accessory'. ${ }^{33}$ Rather than being a second-order representation of a first-order reality (or in Plato's terms a third-order imitation of a secondorder reality that is itself a weak model of the Form), the rhetorical dimensions of linguistic works have a direct impact on the world in working upon the listener or reader. Since both poetics and rhetoric are primarily arts of language, however, there are points at which Aristotle's categories intersect, and as Clark Hulse argues, " "poetics" never exists in isolation, and is always overlapping, contesting, combining, and separating from the other arts, especially the arts of rhetoric, music, philosophy, theology and even geometry. It is precisely in those zones of interaction that theorists are best able to work out the important issues of poetics, concerning the nature, function, and forms of literature'. ${ }^{34}$ It is for this reason that Hulse employs the term 'aesthetics', in order to mark the co-implication of poetics with other domains of artistic production and enquiry, in particular those which are non-linguistic. Yet this does seem to leave aesthetics as a largely strategic category in which all discourse on art (broadly conceived) might be contained. As such, it fails to occupy a systemic position similar to that envisaged in the Kantian critical project.

This mimetic inheritance can be read a little differently. Translation of mimesis as 
'representation' rather than 'imitation' offers a way out of the problem posed by the apparent secondariness of literature, but we need to remember that in the early modern period imitation does not itself have negative connotations. ${ }^{35}$ Equally, linguistic arts are frequently related to the other arts, even in attempts to define poetry itself. As Sir Philip Sidney proposes in A Defence of Poetry, perhaps the most famous of English Renaissance treatises on art: 'Poesy is ... an art of imitation, for so Aristotle termeth it in the word $\mu$ í $\mu \eta \iota^{\prime}$ [mimesis] - that is to say, a representing, counterfeiting, or figuring forth - to speak metaphorically, a speaking picture - with this end, to teach and delight. ${ }^{36}$ Here we see a positive valuation of imitation (mimesis), but one that is valued in particular because it has a specific purpose, to teach and to delight. The figure of the 'speaking picture' recognises that the figures and images of poetry are already metaphorically crossing from language into another realm (and this is, of course, what metaphor means, 'to carry across'). For Sidney, both pleasure and moral content must be present. The teaching invoked here is what Brian Vickers has called the ethical-rhetorical function of early modern literature, and Sidney recognises that this lesson is unlikely to be successful if the mode of instruction is unpalatable. ${ }^{37}$ This is in part why, for Sidney, poetry is to be preferred to historical writing, or indeed philosophy. Literature, according to this definition, fails to recognise a clear distinction between poetics and rhetoric, partaking of both in its attempts to delight as it persuades. There is seemingly no purity or autonomy to poetics, in that it always attempts to act within the world, but what is the nature of this action? What is it that literature as poetry teaches?

The eminence of poetry, for Sidney, comes from the idea that the poet is a maker.

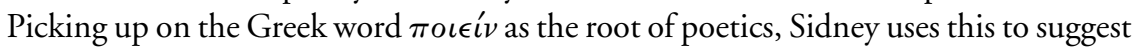
that poetry cannot be relegated to the status of mere copying. ${ }^{38}$ Noting the reliance of the astronomer, the geometrician and arithmetician, philosophers both natural and moral, the lawyer and historian, and others, on objects and rules (including in this the world and nature), Sidney argues that:

Only the poet, disdaining to be tied to any such subjection, lifted up with the vigour of his own invention, doth grow in effect another nature, in making things either better than nature bringeth forth, or, quite anew, forms such as never were in nature, as the Heroes, Demigods, Cyclops, Chimeras, Furies, and such like: so as he goeth hand in hand with nature, not enclosed within the narrow warrant of her gifts, but freely ranging only within the zodiac of his own wit. Nature never set forth the earth in so rich tapestry as divers poets have done; neither with so pleasant rivers, fruitful trees, sweet-smelling flowers, nor whatsoever else may make the too much loved earth more lovely. Her world is brazen, the poets only deliver a golden. ${ }^{39}$

Here, then, is a treatise on poetics that emphasises the possibility of going beyond rules and prescriptions. Instead of a comparison between nature and art in which the representation is able to go in only one direction, from nature to art, nature is held up to the richness of art and is found wanting. There is a line of argument in the Platonic inheritance that would accept this reversal of the relationship of art to nature while retaining a sense of art as a secondary manifestation. Here it could be argued 
that art offers access to the Forms that is equivalent to that offered by objects in nature (that is, to sense-experience), and is thus not tertiary compared to a secondary reality, but is still no better than secondary. Despite this secondarity, Sidney asserts the possibility of moving beyond sense-perception, beyond the world, beyond 'subjection', beyond history (conceived of as the constraint of saying 'what really happened'). What might be read as irresponsibility in the face of history is revealed to be in the service of a higher notion of truth. Such a truthful element, which might be seen as a moment of utopian invention, carries with it (like all utopias) the negative recognition that the world of the senses from which it is freeing itself is imperfect, or fallen. Such a recognition would certainly accord with Sidney's Protestantism. But from the perspective of our discussion, this movement beyond history may be read as an attempt to offer a truly historical cognition of the world.

In this allusion to a truth beyond a mimetic relation to the world, Sidney is also able to combat charges that poets are liars. Sidney argues that 'though he [the poet] recount things not true, yet because he telleth them not for true, he lieth not' (53). The truth lies in the moral example, not in the fiction through which it is conveyed, and the emphasis is again on persuasion, since as he notes earlier in the Defence, 'a feigned example hath as much force to teach as a true example' (36). The truth of the true example has no moral validity beyond that of the truth which may appear through a fiction, but this does not entail upon the writer any necessity to claim that the fiction is itself true. This insight is not the subject of unalloyed joy, however. Only poetry can deliver a vision of the golden world, but the pleasure that this produces cannot free itself entirely of the painful tarnish of its brazen counterpart. Brass is, of course, an alloy, a combination of elements that could only mistakenly be associated with purity. The poet may be able to offer a glimpse of this purity, but his status as maker firmly places his work within the world of objects. Poetry, as defined here by Sidney, is co-extensive with the world but opens the space for critical engagement with that world. Its speaking pictures, as mirrors up to nature, open a space for reflection.

\section{Back to modernity}

In this context of debates around the term early modern, everything hinges on the word 'modern' (although it would also be worth, in another place, pausing over the word 'early'). ${ }^{40}$ If we simply abandon the modern sense of aesthetics on the grounds of some notion of fidelity to periodised chronology, can the concept of the early modern be retained, or must it similarly be jettisoned? The Habermasian view of modernity that Bernstein elaborates makes clear the centrality of the aesthetic to its definition, however alienated that aesthetic may be, and indeed aesthetics is crucial to post-Kantian accounts of philosophical modernity as modernity. The consequences for those attached to the term early modern would seem to be that, without the elaboration of an effective role for what we would now call aesthetics, the early modern will cease to bear any relation to modernity that might afford any genuinely critical purchase. The force of the term early modern threatens to dissipate along with the aesthetic, revealing itself as an indefinable concept, without any referent in the 'world' (and there are several pos- 
sible ways in which world might be conceived here) ${ }^{41}$ In other words, the narrativisation of modernity that the term early modern implies would reveal that the sense of the word modern would have to remain open, perhaps even empty. Furthermore, the concept of the early modern would also appear to have no necessary relation to the concept and narrative of history upon which historicism depends. What seems on the verge of appearing, then, is a historicism with no securely knowable connection to history. If historicism does not seem to provide a reliable conceptual scheme, then, how are we to think about the relationship between literature, aesthetics and history?

One answer would seem to be offered by a return to rhetoric and poetics, here conceived precisely in terms of their combination of persuasion and force with pleasure. Rhetoric opens the relation of text to world, recognising that language as art (the arts of language) can only be gifted autonomy through a violent separation. This is fundamental to early modern notions of poetics that stress an ethical-rhetorical dimension to art. It is this dimension that promises art's connections to truth and cognition. Early modern discourse on the aesthetic domain itself exhibits an awareness of the interrelation of pleasure and pain, and this is activated through the dual recognition that (as part of the world) it always occupies a fallen, secondary position with respect to a transcendental realm, and simultaneously that any glimpse of that realm is only possible through an act of invention, imagination or desire. As an act, art does not fall outside that which is available to sense-perception, but it is not simply bounded by it. Indeed, it is this doubled or enfolded act of (re)cognition that art makes possible, both in spite of and because of its secondarity (as mimesis or representation). Kantian modernity, precisely located in this violent separation and in the mourning that ensues, is a doubling of the recognition that the interaction of poetics and rhetoric ensures. Prior to the Kantian critical philosophy is not a happily unified realm in which aesthetics might be observed in harmony with pure and practical reason, and this is what spurs Kant on, but the mourning that Bernstein posits is itself an enfolded version of the pleasure and pain that art produces through and as (rhetorical) force. Such a force offers the pleasurable pain of reflective thought (of thought as reflection). Rhetoric and poetics, at the points at which they intersect, always seem to be aware of their loss (the golden world of unity). Modernity's sense of loss is thus a doubling, a double mourning; we have lost the unity of reason, but have also lost the rhetori$\mathrm{cal} /$ poetical discourse that allowed us to recognise that such unity was always already lost. The recognition of this loss can only come about through a questioning of aesthetics itself; it cannot simply be thought from a position securely 'outside' it. Art as poetics, even before the rise of aesthetics, was always already alienated. This is what an early modern 'aesthetic', in the form of rhetoric and poetics, can tell us.

\section{Notes}

A version of this piece was presented in a session organised by John Joughin and Simon Malpas at Post-Theory: Politics, Economics and Culture, De Montfort University, 6-8 September 2001. I am grateful to them, to the conference organisers (Gary Day and Andy Mousley), and to the participants for comments. 
1 Both ends of this period have been the topic of some debate, and it is stretched at times from 1450 to around 1800 . This is not the place to reopen such discussions.

2 For definitions of new historicism see, among many possible sources, H. Aram Veeser (ed.), The New Historicism (London: Routledge, 1989); R. Wilson and R. Dutton (eds), New Historicism and Renaissance Drama (Harlow: Longman, 1992); and L. A. Montrose, 'Renaissance literary studies and the subject of history', English Literary Renaissance, 16 (1986), 5-12.

3 On the term itself, see, among many other texts which might be cited here, D. Aers, 'A whisper in the ear of the early modernists; or, reflections on literary critics writing the "history of the subject"' in Aers (ed.), Culture and History 1350-1600 (Detroit: Wayne State University Press, 1992), pp. 177-202; L. Charnes, 'We were never early modern' in J. Joughin (ed.), Philosophical Shakespeares (London: Routledge, 2000), pp. 51-67; H. Dubrow, 'The term early modern', PMLA 109 (1994), 1025-6.

4 New historicism is not confined to Renaissance studies, but this has been the area upon which it has had the strongest impact. Like 'theory' in general, the new historicism has, of course, been pronounced dead. I take up this notion elsewhere in a piece entitled 'theory.after.life' (forthcoming).

5 See Greenblatt's essay, 'Towards a poetics of culture' in Learning to Curse: Essays in Early Modern Culture (London: Routledge, 1990), pp. 146-60.

6 C. Gallagher and S. Greenblatt, Practicing New Historicism (Chicago: University of Chicago Press, 2000), p. 10.

7 See, for example, Greenblatt's essay, 'Resonance and wonder' in Learning to Curse, pp. 161-83 and his Marvelous Possessions: The Wonder of the New World (Oxford: Clarendon Press, 1991). For a rigorous analysis of 'wonder' in Greenblatt's work, see C. Colebrook, New Literary Histories: New Historicism and Contemporary Criticism (Manchester: Manchester University Press, 1997), ch. 9, esp. pp. 214-19.

8 Sadly, such attention to particularity is rarely extended to other critical modes.

9 'Social energy' becomes a key term in Greenblatt's work in his Shakespearean Negotiations: The Circulation of Social Energy in Renaissance England (Oxford: Clarendon Press, 1988).

10 Gallagher and Greenblatt, Practicing New Historicism, p. 11.

11 Ibid., pp. 5-8, 13. For a sense of Herder's place within the German Romantic/Idealist context, see D. O. Dahlstrom, 'The aesthetic holism of Hamann, Herder, and Schiller' in K. Ameriks (ed.), The Cambridge Companion to German Idealism (Cambridge: Cambridge University Press, 2000), pp. 76-94.

12 A general, if far from generous, sense of this rubric might be discerned in Harold Bloom's aligning of new historicists (in several places in his work) with what he calls the 'School of Resentment'. For a typically polemical passage, see the prologue to his How to Read and Why (London: Fourth Estate, 2000). Also typically, when Gallagher and Greenblatt respond to Bloom he is not even named (never mind cited) in the text, his name appearing only in the index.

13 See H. Grady, The Modernist Shakespeare (Oxford: Oxford University Press, 1991); Shakespeare's Universal Wolf (Oxford: Oxford University Press, 1996); and, as editor, Shakespeare and Modernity: Early Modern to Millennium (London: Routledge, 2000).

$14 \mathrm{H}$. Grady, 'Renewing modernity: changing contexts and contents of a nearly invisible concept', Shakespeare Quarterly, 50: 3 (1999), 268-84, p. 272. The cited passage ends with a note to Greenblatt, Renaissance Self-Fashioning: From More to Shakespeare (Chicago: University of Chicago Press, 1980); C. Belsey, The Subject of Tragedy: Identity and Difference in Renaissance Drama (London: Methuen, 1985); and J. Dollimore, Radical Tragedy: 
Religion, Ideology, and Power in the Drama of Shakespeare and his Contemporaries, 2nd edn (Hemel Hempstead: Harvester Wheatsheaf, 1989).

15 Grady, 'Renewing modernity', p. 276.

16 Ibid., p. 278.

17 Ibid., p. 284.

18 J. M. Bernstein, The Fate of Art: Aesthetic Alienation from Kant to Derrida and Adorno (Cambridge: Polity, 1992), p. 5.

19 For an elaboration of this sketch, which suggests that this concern for aesthetics characterises what is called continental philosophy, see P. Osborne (ed.), From an Aesthetic Point of View (London: Serpent's Tail, 2000).

20 A. Bowie, 'German Idealism and the arts' in Ameriks (ed.), The Cambridge Companion to German Idealism, p. 242.

21 Ibid., p. 243.

22 Bernstein, The Fate of Art, pp. 4-5.

23 Ibid., p. 64. Kant's example is to be found in the opening paragraph of $\$ 54$ of the Critique of Judgement.

24 On the relation between spectrality and anachronism, see Derrida, Spectres de Marx: L'État de la dette, le travail du deuil et la nouvelle Internationale (Paris: Galilée, 1993)/Specters of Marx: The State of the Debt, the Work of Mourning, and the New International, trans. P. Kamuf (New York: Routledge, 1994).

25 C. Chase, 'Literary theory as the criticism of aesthetics: De Man, Blanchot, and Romantic "allegories of cognition"' in C. Caruth and D. Esch (eds), Critical Encounters: Reference and Responsibility in Deconstructive Writing (New York: Rutgers University Press, 1995), pp. 42-91, p. 44.

26 See C. Hulse, 'Tudor aesthetics' in A. F. Kinney (ed.), The Cambridge Companion to English Literature, 1500-1600 (Cambridge: Cambridge University Press, 2000), pp. 29-63; T. J. Reiss, 'Cartesian aesthetics' in G. P. Norton (ed.), The Cambridge History of Literary Criticism: Volume 3 The Renaissance (Cambridge: Cambridge University Press, 1999), pp. 511-21. For a discussion which touches on these concerns, see J.-F. Lyotard, 'Defining the postmodern', and P. Lacoue-Labarthe, 'On the sublime', trans. G. Bennington, in L. Appignanesi (ed.), Postmodernism: ICA Documents (London: Free Association, 1993 [1989]), pp. 7-18. Both take up this question of the relation of aesthetics to its prehistory. There is perhaps an analogy to be drawn between the line of enquiry that I am following here and the problem posed by psychoanalysis. Greenblatt, for example, suggests that 'psychoanalysis is the historical outcome of certain characteristic Renaissance strategies'. He further suggests that: 'psychoanalytic interpretation seems to follow upon rather than to explain Renaissance texts ... psychoanalytic interpretation is causally belated, even as it is causally linked: hence the curious effect of a discourse that functions as if the psychological categories it invokes were not only simultaneous with but even prior to and themselves causes of the very phenomena of which in actual fact they were the results.' It should be noted, however, that historicism can differentiate itself from psychoanalysis only by reference to psychoanalysis. In this sense it always comes after psychoanalysis, and cannot (itself belatedly) be rigorously separated from it. See Greenblatt, 'Psychoanalysis and Renaissance culture', in Learning to Curse, pp. 131-45, pp. 144 and 142.

27 For a fascinating discussion, see G. Genette, Paratexts: Thresholds of Interpretation, trans. J. E. Lewin (Cambridge: Cambridge University Press, 1997). Originally published as Seuils (Paris: Éditions de Seuil, 1987).

28 My use of terms beginning with 'meta-' is purely strategic. It is by no means certain that it 
would be possible to distinguish clearly between a language that was poetic/rhetorical and a language that would be able to comment upon poetics/rhetoric from a 'safe' distance. This parallels the comments by Derrida and others about metalanguage, to the effect that 'there is no metalanguage, which is another way of saying that there is only metalanguage'. For a clear summary, see J. Culler, On Deconstruction: Theory and Criticism after Structuralism (London: Routledge, 1983), p. 199.

29 Aristotle, Poetics, in The Complete Works of Aristotle, ed. J. Barnes, 2 vols (Princeton: Princeton University Press, 1984), 2, p. 2316 (1447a).

30 Plato, The Collected Dialogues, including the Letters, eds E. Hamilton and H. Cairns (Princeton: Princeton University Press, 1961 [1989]), p. 821 (596e).

31 Plato, Republic, X, p. 827 (602b).

32 In a much-discussed passage, Austin writes: 'Language', spoken on stage, used in a poem or soliloquy, 'is in special ways - intelligibly - used not seriously, but in ways parasitic upon its normal use - ways which fall under the doctrine of the etiolations of language. All this we are excluding from consideration.' See How To Do Things With Words, 2nd edn (Oxford: Oxford University Press, 1976), p. 22.

33 Aristotle, Rhetoric, in The Complete Works of Aristotle, 2, p. 2152 (1354a).

34 Hulse, 'Tudor aesthetics', p. 35.

35 See, for example, the comments of T. M. Greene: 'The imitation of models was a precept and an activity which during that era embraced not only literature but pedagogy, grammar, rhetoric, esthetics, the visual arts, music, historiography, politics, and philosophy. It was central and pervasive', The Light in Troy: Imitation and Discovery in Renaissance Poetry (New Haven: Yale University Press, 1982), p. 1.

36 Sidney, A Defence of Poetry, ed. J. A. Van Dorsten (Oxford: Oxford University Press, 1966 [1991]), p. 25.

37 B. Vickers, 'Introduction', in Vickers (ed.), English Renaissance Literary Criticism (Oxford: Oxford University Press, 1999), pp. 1-55, p. 10.

38 For a recent text which begins from a similar recognition, see J.-L. Nancy, Résistance de la poésie (Bordeaux: William Blake \& Co., 1997).

39 Sidney, A Defence of Poetry, pp. 23-4.

40 I am grateful to Nicholas Royle for a gentle reminder of the necessity of paying attention to 'early', and I hope that he will accept this promise to do so, even if I cannot fulfil that promise here.

41 See, notably, J.-L. Nancy, The Sense of the World, trans. J. S. Librett (Minneapolis: Minnesota University Press, 1997). First published as Le sens du monde (Paris: Galilée, 1993). 